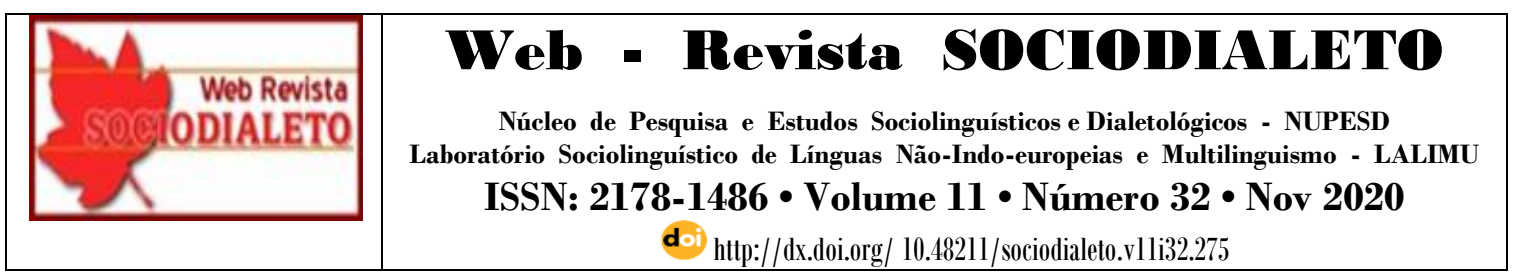

\title{
PORTUNHOL - LÍNGUA, INTERLÍNGUA OU DIALETO?: UMA REVISÃO BIBLIOGRÁFICA
}

\author{
Alessandra Moraes de Andrade (PPGEL-UEPG) ${ }^{1}$ \\ amoraesdeandrade@hotmail.com \\ Valeska Gracioso Carlos (UEPG) ${ }^{2}$ \\ vgracioso@uol.com.br
}

\begin{abstract}
RESUMO: Esta pesquisa mostra uma classificação do portunhol como língua, interlíngua, dialeto, ou outra variante, de acordo com seu contexto de uso, a partir de estudos relacionados ao tema. Partiu-se de uma pesquisa bibliográfica procurando conceitos e definições sobre língua, interlíngua, dialeto e portunhol. Posteriormente procurou-se estudos específicos de classificação do portunhol, nos quais foi constatado que esta variante pode ser classificada de acordo com os seguintes contextos: portunhol de fronteira, portunhol no contexto de ensino/aprendizado e portunhol literário. Por causa da maior concentração de estudos relacionados, o portunhol de fronteira foi limitado à fronteira Brasil - Uruguai. Quanto aos resultados, verificou-se que o portunhol de fronteira, apesar da maior parte dos estudos classificá-lo como dialeto ou variedade do português, pode ser designado como língua. O portunhol no contexto de ensino/aprendizagem, apesar de ser considerado preferentemente uma interlíngua, pode ser considerado uma translíngua. Finalmente, com base nos estudos pesquisados, percebe-se que o portunhol literário é uma língua.
\end{abstract}

PALAVRAS-CHAVE: Portunhol. Interlíngua. Fronteira.

\begin{abstract}
This research shows a classification of portunhol as a language, interlanguage, dialect, or other variant, according to its context of use, based on studies related to the theme. We started with a bibliographic search looking for concepts and definitions about language, interlanguage, dialect and portuguese. Subsequently, specific studies on the classification of portunhol were sought, in which it was found that this variant can be classified according to the following contexts: border portunhol, portunhol in the context of teaching/ learning and literary portunhol. Because of the greater concentration of related studies, border portunhol was limited to the Brazil - Uruguay border. As for the results, it was found that border portuguese, despite most studies classifying it as a dialect or variety of portuguese, can be designated as a language. Portunhol in the teaching/learning context, although it is preferable to be considered an interlanguage, can be considered a translanguage. Finally, based on the researched studies, it is clear that literary portuguese is a language.
\end{abstract}

KEYWORDS: Portunhol. Interlanguage. Border.

\footnotetext{
${ }^{1}$ Mestranda em Estudos da Linguagem na Universidade Estadual de Ponta Grossa (UEPG). E-mail: amoraesdeandrade@hotmail.com

${ }^{2}$ Doutora em Estudos da Linguagem pela Universidade Estadual de Londrina, Professora efetiva do Programa de Mestrado em Estudos da Linguagem na Universidade Estadual de Ponta Grossa (UEPG). Email:vgracioso@uol.com.br
} 


\section{Introdução}

Levando em conta a atual e crescente necessidade de integração entre países próximos, principalmente por razões econômicas e políticas, é importante também ressaltar a necessidade de compreensão das línguas dos países envolvidos, principalmente em zonas fronteiriças, onde as atividades de intercâmbio entre tais países é mais frequente. Em se tratando de contato entre línguas diferentes em zonas fronteiriças, é possível citar o portunhol que, devido à constante interação entre o português e o espanhol e por possuírem características similares na fonologia, na morfologia e na sintaxe, fazendo parte de uma mesma família linguística (o latim), tem ganhado força nas últimas décadas e feito parte até mesmo da escrita de alguns autores literários. O portunhol tem também gerado discussões no âmbito acadêmico, principalmente depois do advento do Mercosul, acordo que tem como principal objetivo o fortalecimento econômico e político, que por sua vez tem exigido uma competência linguística que envolve, principalmente, as línguas espanhola e portuguesa.

A maior parte dos estudos sobre portunhol está concentrada em situações de fronteira; dentre esses estudos pode-se citar duas áreas nas quais as pesquisas estão concentradas: políticas educacionais e linguísticas; e classificação do portunhol. A primeira área se refere a, por exemplo, discussões sobre a necessidade de formalizar o ensino de uma segunda língua nas áreas fronteiriças, assim como implementar políticas que contribuam para o bom relacionamento entre as línguas de fronteira. A segunda se refere a como enquadrar ou denominar o portunhol, no sentido de ser, por exemplo, uma língua, uma interlíngua ou um dialeto. Inicialmente este trabalho se concentrou nessa segunda área, na qual, a partir de estudos em andamento do projeto de Iniciação Científica, percebeu-se que havia uma dificuldade em classificar o portunhol por parte de diversos autores. Confrontando alguns estudos pesquisados nessa área, notou-se uma falta de consenso a respeito do enquadramento do portunhol. Isto motivou a realização de um estudo voltado a uma revisão bibliográfica contemplando a classificação do portunhol à luz de diferentes autores. Durante o levantamento de estudos sobre 


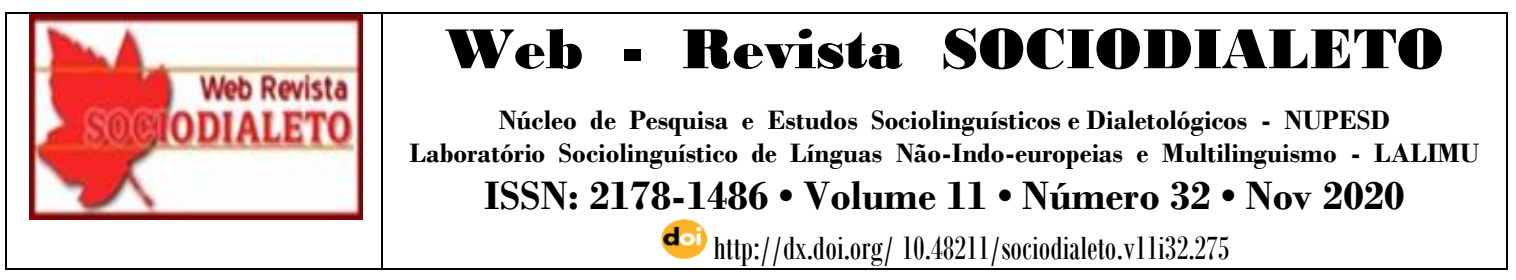

classificação do portunhol, percebeu-se que esta variante depende do contexto ou situação social em que o portunhol é praticado. Assim, a revisão bibliográfica se estendeu à busca de estudos relacionados ao portunhol praticado em situações de fronteira, situações de ensino/aprendizado e situações de portunhol na escrita de obras literárias. Sendo assim, este trabalho procurou enquadrar o portunhol em alguma variante linguística (tal como língua, interlíngua ou dialeto, entre outras) segundo o contexto em que é praticado, a partir de uma análise de estudos relacionados ao tema.

\section{Material e métodos}

Para atender os objetivos de pesquisa, neste trabalho seguiram-se as seguintes etapas: pesquisa bibliográfica, revisão de literatura e análise de classificação.

A pesquisa bibliográfica teve como objetivo averiguar a respeito de conceitos sobre língua, interlíngua, dialeto e portunhol. Consultou-se bibliografia básica principalmente no tocante a conceitos sobre língua e dialeto, que possuem autores clássicos. Também se complementou a pesquisa bibliográfica com artigos acadêmicos, especialmente na parte de conceitos de portunhol. Os conceitos pesquisados serviram de base para realizar a Revisão de Literatura, análise e classificação do portunhol.

A revisão de literatura consistiu no levantamento de estudos relacionados à classificação do portunhol, procurando averiguar se este se enquadra no campo de língua, interlíngua ou dialeto. Esta busca consistiu na seleção de artigos acadêmicos presentes em periódicos e revistas da área assim como artigos de congressos, simpósios e eventos similares. A pesquisa de artigos foi realizada principalmente nas bases de dados do Google Acadêmico, Periódicos CAPES e Scielo. Para realizar as buscas nessas bases utilizaram-se palavras chave como: portunhol, portunhol-língua, portunhol-interlíngua e portunhol-dialeto, entre outras. Assim selecionaram-se somente artigos relacionados à classificação do portunhol, descartando artigos cujo foco não seja a classificação do portunhol ou não tivessem conteúdo específico dos assuntos tratados 


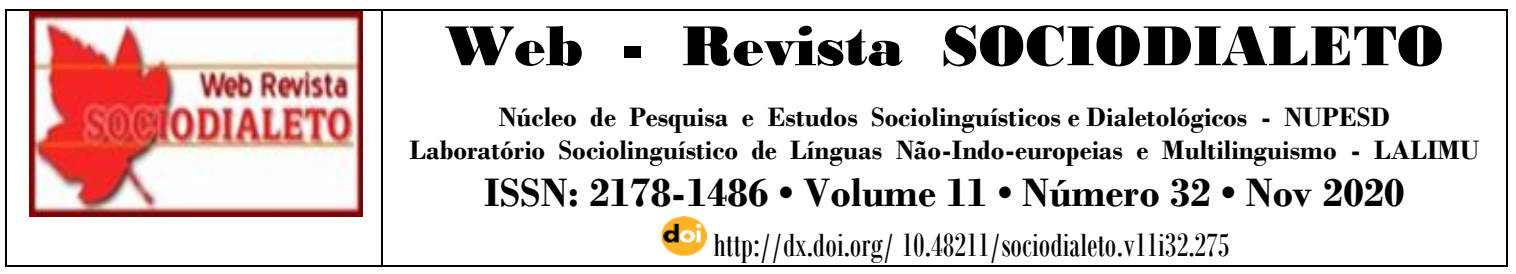

nesta pesquisa. Esta fase também foi complementada com pesquisas de teses e dissertações relacionadas com a classificação do portunhol.

Durante o levantamento de estudos sobre classificação do portunhol, percebeuse que esta variante também pode ser classificada conforme o contexto ou situação social onde o portunhol é praticado. Assim, a revisão de literatura se dividiu e se estendeu à busca de estudos relacionados ao portunhol praticado em situações de fronteira, situações de ensino/aprendizado e situações de portunhol na escrita de obras literárias. Nesses casos se procurou artigos, teses e dissertações que abordassem sobre as características do portunhol praticado em cada uma desses contextos.

Cabe ressaltar que no início deste trabalho, o objetivo principal proposto estava voltado à classificação do portunhol como língua, interlíngua ou dialeto; no entanto, devido à constatação de que esta classificação também depende do contexto onde o portunhol é praticado, o objetivo da pesquisa se estendeu a classificar o portunhol de acordo com o contexto de fronteira, ensino/aprendizado e escrita em obras literárias.

Uma vez feita a revisão de literatura sobre portunhol nos contextos de fronteira, ensino/aprendizado e escrita em obras literárias, se procedeu à análise desses estudos e posterior classificação do portunhol. A análise dos estudos buscou obter dados para caracterizar o portunhol em cada um dos contextos estudados. A análise também procurou achar subsídios para classificar o portunhol em cada um desses contextos. A análise de classificação teve como base os conceitos elencados na fase de Pesquisa Bibliográfica, no entanto foram achados novos conceitos na fase de Revisão de Literatura, que também colaboraram para a classificação final.

\section{Resultados e discussão}

Conforme as pesquisas realizadas sobre estudos de classificação do portunhol, assim como outros estudos relacionados, foi constatado que o portunhol pode ser classificado de acordo com três situações: portunhol de fronteira, portunhol no contexto 


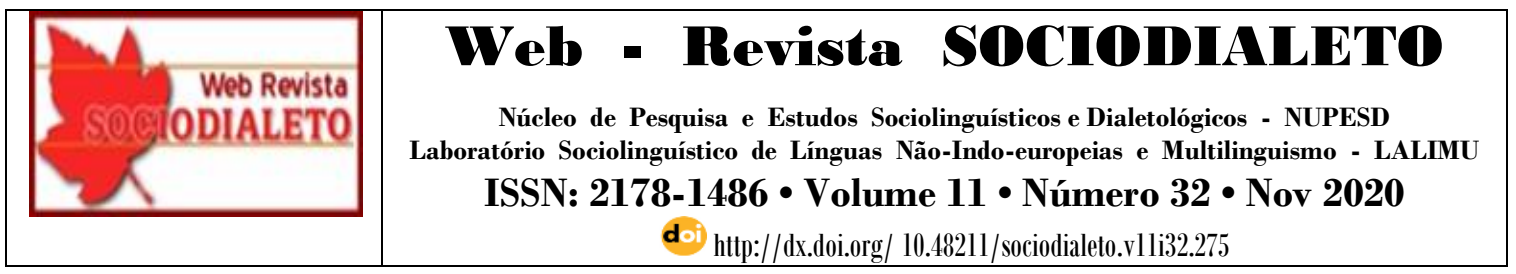

de ensino/aprendizado (que será denominado portunhol de L1 para L2/LE) e portunhol poético ou literário, como mostra a Figura 1.

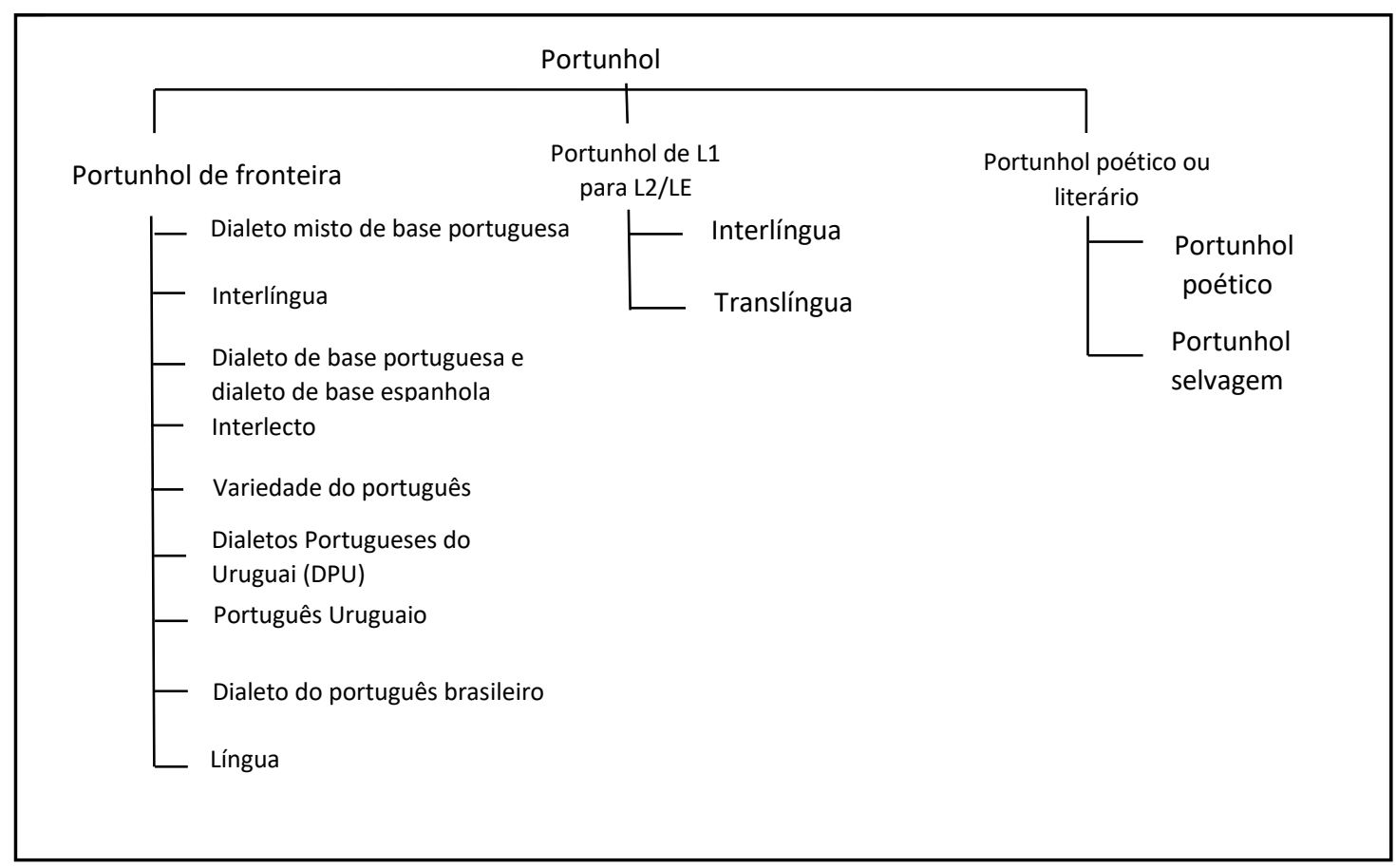

Fonte: Moraes (2019)

De modo geral, o portunhol na fronteira recebeu várias denominações ao longo do tempo. Atualmente o mais aceito é tratar o portunhol como dialeto ou variedade do português brasileiro, no entanto há autores que o enquadram como língua ou interlíngua. O portunhol de L1 para L2/LE se refere a situações de aprendizado de uma segunda língua ou língua estrangeira, o qual não necessariamente acontece na fronteira. Os estudos pesquisados nesse sentido apontam para enquadrar o portunhol como interlíngua ou translíngua. O portunhol poético ou literário é encontrado principalmente em obras literárias. O portunhol poético tem os mesmos moldes que o portunhol de fronteira. Já o portunhol selvagem, além de usar português e espanhol, também utiliza guarani, no entanto pode incluir inglês, francês e italiano, entre outras, conforme o estilo do autor. 


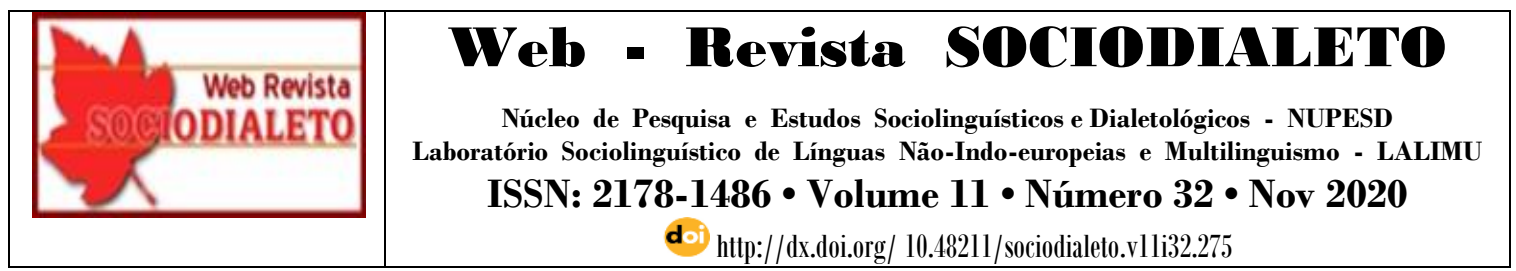

Conforme a classificação mostrada na Figura 2, a seguir serão mostrados os resultados da Revisão de Literatura para o portunhol de fronteira, portunhol de L1 para L2/LE e portunhol poético ou literário.

\subsection{Portunhol de fronteira}

Conforme Chasteen (2003) e Souza e Prado (2004), em meados do século XIX uma parte importante das cidades do Norte do Uruguai estava composta por propriedades rurais pertencentes a brasileiros que faziam parte da elite da fronteira do Rio Grande do Sul. Assim, por causa da presença massiva de brasileiros, a língua mais falada no norte do Uruguai era o português. Isto preocupou às autoridades políticas e intelectuais de Montevideo, o que mais tarde levou a instaurar uma lei que formalizava a educação primaria em língua espanhola em todo o país. A entrada do espanhol na educação formal na região Norte do Uruguai com maioria de lusofalantes, deu lugar a uma sociedade bilíngue, juntamente com o surgimento de uma nova variedade linguística: o portunhol. Por causa do conflito entre as duas línguas e os usos dados a cada uma delas, a sociedade fronteiriça do norte do Uruguai tem sido caracterizada como diglóssica ${ }^{3}$ (URUGUAY, 2013), sendo o espanhol a variedade alta e o portunhol a variedade baixa. Dessa forma, como explica a pesquisadora Ana Maria Carvalho (GLOBO, 2015), o portunhol é usado em casa, na rua e no bairro; já o espanhol é usado nas instituições públicas, por exemplo no banco.

As pesquisas acadêmicas sobre o portunhol fronteiriço do Norte de Uruguai e sua adequada classificação se remontam à inícios da década de 60, com os estudos de Rona (1963) sobre a variedade do português falado na fronteira Brasil - Uruguai. Nesses estudos o falar fronteiriço é colocado primeiramente como dialeto fronteiriço misto de base portuguesa, o qual mistura português falado no Rio Grande do Sul com espanhol

\footnotetext{
3 Segundo Ferguson (1972), diglossia é uma situação linguística em que além do dialeto regional (variedade baixa) falado em uma comunidade, há uma variedade linguística sobreposta (variedade alta), geralmente mais complexa e com mais prestígio, que essencialmente é aprendida na educação formal e usada em situações formais, mas que não é usada em situações de conversação ordinária.
} 


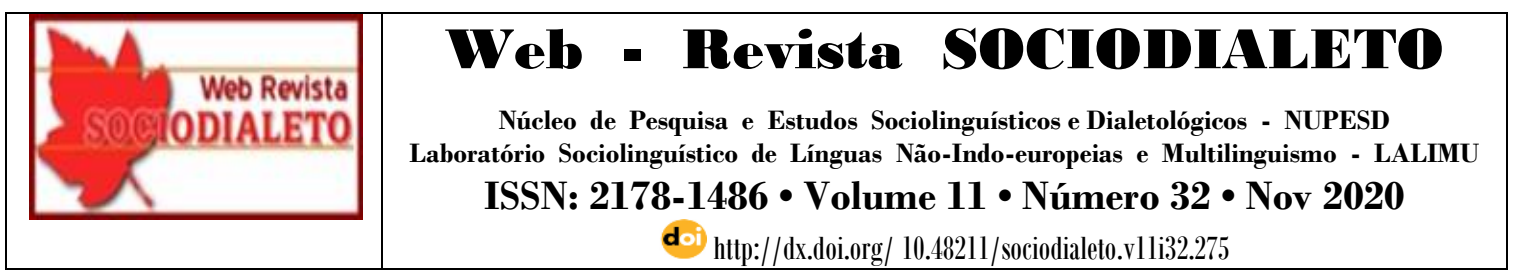

falado no Uruguai. Posteriormente, Rona (1965) dividiu as práticas linguísticas da fronteira em falantes de português, falantes de espanhol e falantes de fronteiriço (fronterizo). $\mathrm{O}$ fronteiriço foi dividido pelo mesmo pesquisador em fronteiriço de base portuguesa (fronterizo portugués) e fronteiriço de base espanhola (fronterizo castellano). O primeiro tem o português como base e é influenciado pelo espanhol; já o segundo tem o espanhol como base e é influenciado pelo português.

No entanto, conforme Thun, Forte \& Elizaincín (1989), estudos posteriores aos de Rona não confirmam a separação de dialetos sugerida por este autor, entretanto, verificou-se indícios de uma variação diatópica e diastrática do português (diversidade linguística regional ou geográfica e de um grupo social para outro, respectivamente). Assim, somente poderia se afirmar com certeza que no Norte de Uruguai se fala variedades do português, descartando a possibilidade de um dialeto de base espanhola.

Os estudos de Hensey (1969) são considerados os primeiros no âmbito da sociolinguística, abrindo assim espaço para o estudo da fala da fronteira também desde o ponto de vista das práticas sociais. Segundo esse autor, a variedade linguística da fronteira não pode ser simplesmente classificada como uma variante do português ou do espanhol ou como uma variante mista independente, mas que deveria se considerar a possibilidade de tratá-la como interlíngua ou interlecto (HENSEY, 1980). No primeiro caso o falar fronteiriço seria uma interlíngua visando evoluir do espanhol para o português como língua alvo ou vice-versa. No segundo caso o falar da fronteira poderia ser visto como "uma fase do desenvolvimento linguístico da criança fronteiriça" (HENSEY, 1980, p. 59), ou seja, os fronteiriços que tiverem o português como língua materna, aprendem a falar espanhol na escola e assim o usam como segunda língua, sendo assim o dialeto regional poderia ser chamado de interlecto. No entanto, em um estudo publicado posteriormente pelo mesmo autor (HENSEY, 1982), depois de uma análise lexical, fonológica, gramatical e morfossintática, conclui que a caracterização do fronteiriço como variedade do português é inquestionável. Nessa pesquisa, Hensey mostra, dentre outros aspectos, que o dialeto fronteiriço possui empréstimos do espanhol que o pesquisador atribui ao entorno formal acadêmico onde o espanhol é a 


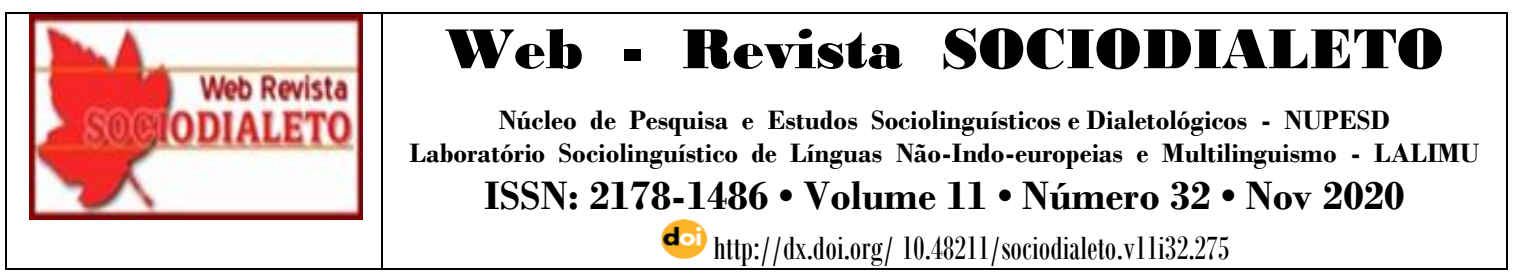

língua de instrução. Também mostra que aspectos fonológicos e de morfossintaxe do fronteiriço são do português.

Os autores Elizaincín, Behares e Barrios (1987) apresentam um estudo em que mostram a fronteira como uma sociedade bilíngue e diglóssica, na qual os habitantes da cidade usam alternadamente um dialeto do espanhol (falado em contextos formais e em contextos familiares de classe média e alta) e um dialeto do português falado no Uruguai, usado em situações informais e contextos familiares da classe baixa. Assim, na cidade ocorre o que os autores denominam de bidialetismo. Já os habitantes das periferias e das zonas rurais são monolíngues e falam um dialeto misto, resultado do contato entre o português e espanhol. Os autores agrupam os dialetos falados na fronteira sob o nome de Dialetos Portugueses do Uruguai (DPU). Conforme os autores, o termo plural "dialetos" se refere a que na fronteira não acontece uma situação linguística uniforme, mas variável. Já o termo "portugueses" se refere a que os dialetos possuem como denominador comum a base portuguesa.

O estudo de Carvalho (1998) designa por primeira vez aos dialetos portugueses falados na fronteira como português uruguaio, os quais, para a autora, são variedades do português brasileiro. Para a autora, o português falado pelos habitantes bilíngues das zonas urbanas da fronteira é uma variedade do português brasileiro urbano e não um dialeto do português do Uruguai, como sustentavam Elizaincín, Behares e Barrios (1987). Já o dialeto praticado pelos habitantes monolíngues das zonas periféricas e rurais corresponde, para a autora, ao fronteiriço de base portuguesa relatado por Rona (1965). Sendo assim, a autora afirma que na fronteira se fala duas variantes do português brasileiro. A autora ainda sustenta (Carvalho, 2003) que o português uruguaio é um continuum entre o português culto das zonas urbanas e o português não culto das zonas rurais e que este último, por causa da urbanização, sofre mudanças em direção às formas mais cultas do português, que são mais prestigiadas nas zonas urbanas. Foi a partir dos estudos de Carvalho que houve um real reconhecimento de que no Norte do Uruguai se fala uma variedade legítima do português, promovendo políticas educacionais e linguísticas como o ensino bilíngue nas escolas fronteiriças. 
Segundo o estudo de Lipski (2006), o autor admite que o dialeto falado na fronteira contém configurações entrelaçadas que sugerem uma hibridização em lugar de simples transferência bilíngue. Isto justificaria designações tais como fronterizo, o qual sugere uma "terceira língua". No entanto, apesar disso, o autor sustenta que o português falado no Norte do Uruguai é essencialmente um dialeto do português falado na zona rural do Sul do Brasil, com uma pesada mistura de itens lexicais do espanhol e alguma transferência parcial de combinações gramaticais similares, mas não idênticas. A visão de Lipski também é confirmada por Waltemire (2012), que fez um estudo na cidade fronteiriça de Rivera, no Norte do Uruguai. Waltemire conclui que o portunhol de Rivera não é uma nova língua nem uma interlíngua, mas sim um dialeto do português brasileiro. O autor confirma o bilinguismo existente em Rivera e por isso as situações da fronteira deveriam ser tratadas como dialetos bilíngues e não como uma nova língua. $\mathrm{O}$ autor também sugere que não existe uma diglossia entre o espanhol e o português, já que seu estudo comprova que o espanhol ou português é falado conforme os interlocutores e não conforme os estratos sociais. Assim, ele comprova que o espanhol é tão usado quanto o português em situações familiares, por exemplo, dependendo dos interlocutores, assim como o português é usado, por exemplo, em situações informais de trabalho. Isto contraria estudos anteriores que indicam que o português é preferido em casa e o espanhol em situações formais e de trabalho.

Outros autores como Mota (2010; 2012) e Sturza e Tatsch (2016) sugerem que o portunhol poderia ser considerado uma língua. Nesse sentido, Mota argumenta que a zona de fronteira, por ter características próprias de intercâmbio entre os países, pode ser pensada em termos de um "novo território", ao que denomina de território fronteiriço. O portunhol seria uma das línguas que compõem esse território. Essa língua, por não ser gramatizada, se manifesta mais na oralidade da sociedade fronteiriça. Sturza e Tatsch afirmam que o portunhol é uma língua, apoiando-se na sociolinguística aplicada a línguas de contato. As autoras sustentam sua colocação baseadas na afirmativa de Appel e Muysken (1996) de que em situações sociolinguísticas de línguas de contato pode haver alternância de estilo, câmbio linguístico e escolha do repertório 


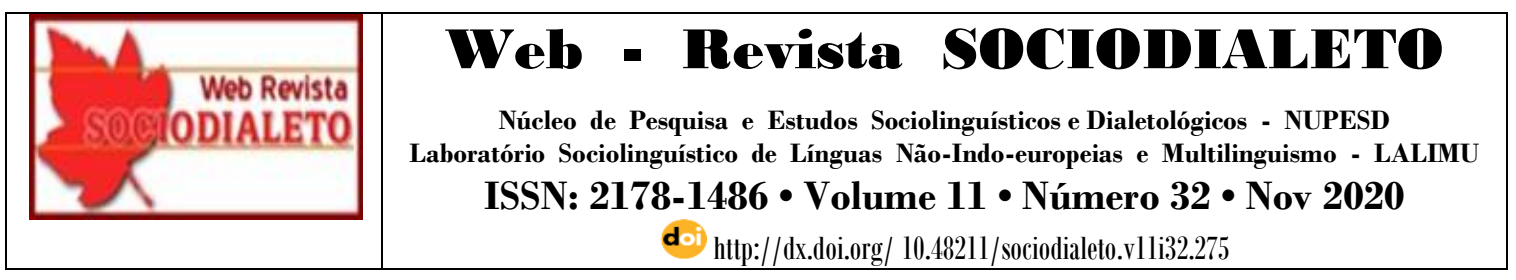

linguístico, entre outros. Assim, para os habitantes da fronteira, o portunhol é a língua escolhida por eles para se expressar e assim afirmar uma identidade fronteiriça, realizando uma escolha política que busca produzir efeitos de sentido, [e] considera sua relação com o interlocutor, seja ele um falante de espanhol, um falante de português ou um falante de Portunhol/lingua de fronteira (STURZA e TATSCH 2016).

O estudo de Morales (2017) tenta elucidar se o portunhol é uma língua, interlíngua ou dialeto, concluindo que seria uma interlíngua, já que há constante interferência do espanhol ou português, conforme a língua mãe de cada falante. Essa interferência se traduz em erros linguísticos que os falantes procuram corrigir constantemente, tentando assim se aproximar da língua alvo. Dessa forma, a oscilação entre português e espanhol depende da competência linguística de cada falante. Essas características condizem com os conceitos de interlíngua expostos anteriormente (SELINKER, 1972; ELLIS, 1997).

Sustentado pela linha de pensamento de autores como Waltemire e Carvalho, entre outros, o trabalho de Pacheco (2017) também confirma que o português uruguaio é uma variedade do português brasileiro. Em seu estudo, Pacheco mostra que o português uruguaio tem aspectos em comum tanto com o português brasileiro gaúcho da fronteira, como com o português brasileiro de modo geral. Assim, "o português uruguaio e o português brasileiro dialogam entre si e são semelhantes em vários aspectos linguísticos" (Pacheco, 2017, p.24). Dessa forma a pesquisadora conclui que há uma continuidade (continuum) dialetal entre o português uruguaio e o português brasileiro, tal como previsto por Carvalho (2003).

O Quadro 1 mostra um resumo dos estudos pesquisados sobre portunhol de fronteira, indicando sua denominação por diferentes autores assim com suas características principais.

É possível observar no Quadro 1 que a maioria dos autores tratam o portunhol de fronteira como dialeto ou variedade do português. De fato, essa classificação é a mais aceita atualmente. No entanto, embora haja poucos autores afirmando ser o portunhol de fronteira uma língua, há razões que justificam este posicionamento. Por exemplo, de 


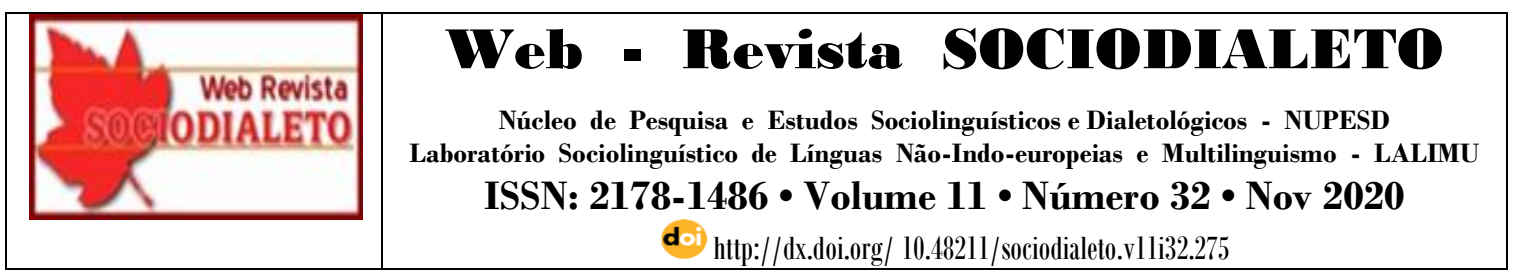

acordo com Coutinho (1976), pesquisador que tem seus estudos voltados à história do surgimento das línguas, a "Língua é a linguagem particularmente usada por um povo", ou seja, ela é construída no cotidiano das comunidades de fala que a praticam tornandose uma identidade desta população. Vai muito além de políticas impostas, de tentar torná-la subalterna e marginalizada porque faz parte daquela população desde que nasceu. O portunhol é único, diferente, com características que não se enquadram a uma norma padrão, mas que é constituído historicamente, socialmente por uma cultura de fronteira.

Quadro 1 - Denominação do portunhol por diferentes autores

\begin{tabular}{|c|c|c|}
\hline $\mathbf{A}$ & Denominação & Características \\
\hline $\begin{array}{l}\text { Rona } \\
(1963)\end{array}$ & $\begin{array}{l}\text { Dialeto } \\
\text { fronteiriço misto }\end{array}$ & $\begin{array}{l}\text { Mistura do português falado na fronteira do Rio } \\
\text { Grande do Sul com o espanhol. Conforme Rona } \\
\text { (1963) este dialeto aparentemente tem base } \\
\text { portuguesa. }\end{array}$ \\
\hline $\begin{array}{l}\text { Rona } \\
(1965)\end{array}$ & $\begin{array}{l}\text { Fronteiriço } \\
\text { (fronterizo) }\end{array}$ & $\begin{array}{l}\text { O fronteiriço é resultado da interação do português } \\
\text { com o espanhol, sendo que pode ser dividido em } \\
\text { dois tipos: fronteiriço de base portuguesa e } \\
\text { fronteiriço de base espanhola. }\end{array}$ \\
\hline $\begin{array}{l}\text { Hen } \\
(198\end{array}$ & & $\begin{array}{l}\text { O fronteiriço não é nem espanhol nem português, } \\
\text { nem formas misturadas ou truncadas dos mesmos, } \\
\text { senão uma interlíngua capaz de evoluir em direção a } \\
\text { uma das duas línguas. }\end{array}$ \\
\hline $\begin{array}{l}\mathrm{H} \\
(1 \\
\end{array}$ & Int & $\begin{array}{l}\text { O aprendizado do espanhol faz parte do } \\
\text { desenvolvimento da criança fronteiriça cuja língua } \\
\text { materna é o português; assim o espanhol é usado } \\
\text { como segunda língua, com empréstimos de } \\
\text { português, resultando no dialeto fronteiriço. }\end{array}$ \\
\hline $\begin{array}{l}\text { Hensey } \\
(1982)\end{array}$ & $\begin{array}{l}\text { Variedade } \\
\text { português }\end{array}$ & $\begin{array}{l}\text { O dialeto fronteiriço possui empréstimos do } \\
\text { espanhol que se devem ao entorno formal acadêmico } \\
\text { onde o espanhol é a língua de instrução. Aspectos } \\
\text { fonológicos e de morfossintaxe do fronteiriço } \\
\text { também são do português. }\end{array}$ \\
\hline $\begin{array}{l}\text { Elizaincín, } \\
\text { Behares e } \\
\text { Barrios }\end{array}$ & $\begin{array}{l}\text { Dialetos } \\
\text { Portugueses do } \\
\text { Uruguai (DPU) }\end{array}$ & $\begin{array}{l}\text { Formas mistas ou dialetos bilíngues de base } \\
\text { portuguesa, resultantes do contato entre português e } \\
\text { espanhol; praticado em situações informais e } \\
\text { contextos familiares pela classe baixa. }\end{array}$ \\
\hline
\end{tabular}




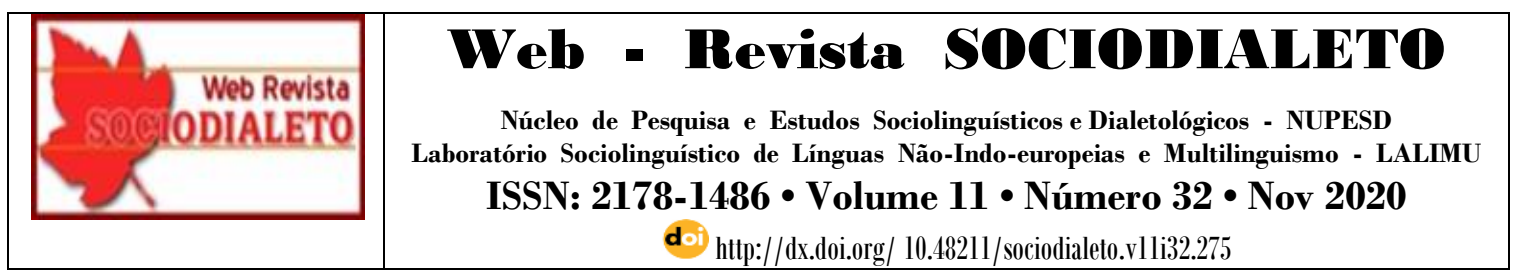

\begin{tabular}{|c|c|c|}
\hline (1987) & & \\
\hline $\begin{array}{l}\text { Carvalho } \\
(1997 ; \\
2003)\end{array}$ & $\begin{array}{l}\text { Português } \\
\text { Uruguaio } \\
\text { Variedade } \\
\text { português } \\
\text { brasileiro }\end{array}$ & $\begin{array}{l}\text { Na fronteira se fala duas variantes do português } \\
\text { brasileiro, que podem ser nomeadas de português } \\
\text { uruguaio. Na zona rural se fala um dialeto de base } \\
\text { portuguesa e nas zonas urbanas se fala uma } \\
\text { variedade do português brasileiro urbano. }\end{array}$ \\
\hline $\begin{array}{l}\text { Lipski } \\
(2006)\end{array}$ & $\begin{array}{l}\text { Dialeto } \\
\text { português } \\
\text { brasileiro }\end{array}$ & $\begin{array}{l}\text { O portunhol do norte de Uruguai (fronterizo) é } \\
\text { essencialmente um dialeto do português rural do Sul } \\
\text { do Brasil, com uma pesada mistura de itens lexicais } \\
\text { do espanhol e alguma transferência parcial de } \\
\text { combinações gramaticais similares mas não } \\
\text { idênticas. }\end{array}$ \\
\hline $\begin{array}{l}\text { Waltemire } \\
\text { (2012) }\end{array}$ & $\begin{array}{l}\text { Dialeto } \\
\text { português } \\
\text { brasileiro }\end{array}$ & $\begin{array}{l}\text { O portunhol não é língua nem interlíngua, mas um } \\
\text { dialeto do português brasileiro. Na fronteira (Rivera) } \\
\text { existem dialetos bilíngues em lugar de uma terceira } \\
\text { língua. }\end{array}$ \\
\hline $\begin{array}{l}\text { Mota } \\
(2012)\end{array}$ & Língua & $\begin{array}{l}\text { O portunhol "é uma das línguas constitutivas dos } \\
\text { sujeitos que compõem a sociedade que habita a } \\
\text { fronteira uruguaio-brasileira [...]. Como uma língua } \\
\text { não gramatizada, historicamente, o portunhol que } \\
\text { circula na fronteira uruguaio-brasileira circunscreve- } \\
\text { se mais amplamente ao domínio da oralidade na } \\
\text { sociedade fronteiriça [...]". (MOTA, 2012, p. 130- } \\
\text { 131) }\end{array}$ \\
\hline $\begin{array}{l}\text { Sturza e } \\
\text { Tatsch } \\
(2016)\end{array}$ & Língua & $\begin{array}{l}\text { "A língua de fronteira, sendo ela designada de } \\
\text { Portunhol ou não, é antes de tudo considerá-la [sic] } \\
\text { uma língua que tem sentido para os sujeitos inscritos } \\
\text { numa comunidade na qual estar entre uma língua e } \\
\text { outra é constitutivo da sua relação identitária." } \\
\text { (STURZA e TATSCH, 2016, p. 96) }\end{array}$ \\
\hline $\begin{array}{l}\text { Morales } \\
(2016)\end{array}$ & Interlíngua & $\begin{array}{l}\text { O portunhol sofre interferência constante do } \\
\text { português ou espanhol, dependendo da língua mãe } \\
\text { de cada falante. Essa interferência se traduz em erros } \\
\text { de linguagem que os falantes tentam corrigir } \\
\text { constantemente. A oscilação entre português e } \\
\text { espanhol depende da competência linguística de cada } \\
\text { falante. }\end{array}$ \\
\hline $\begin{array}{l}\text { Pacheco } \\
\text { (2017) }\end{array}$ & $\begin{array}{l}\text { Variedade } \\
\text { português } \\
\text { brasileiro }\end{array}$ & $\begin{array}{l}\text { O português uruguaio tem aspectos em comum tanto } \\
\text { com o português brasileiro gaúcho da fronteira, } \\
\text { como com o português brasileiro de modo geral. O } \\
\text { português uruguaio e o português brasileiro }\end{array}$ \\
\hline
\end{tabular}




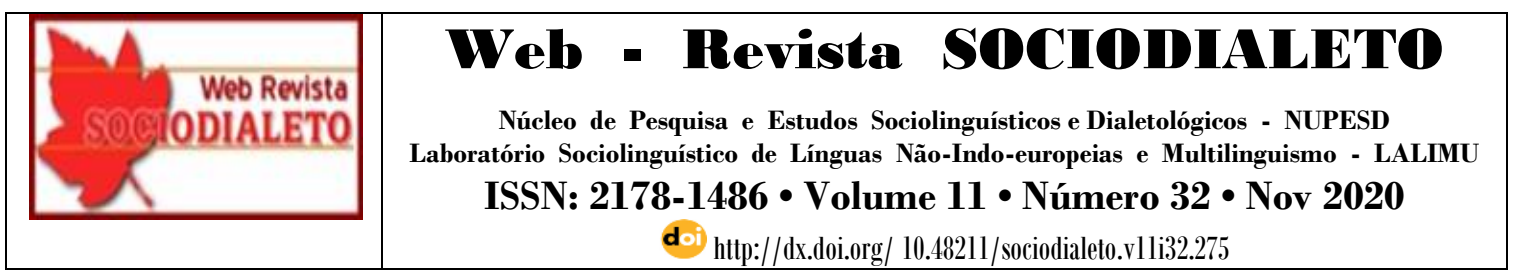

\begin{tabular}{|l|l|l|}
\hline & $\begin{array}{l}\text { dialogam entre si, de forma que há uma continuidade } \\
\text { dialetal entre eles. }\end{array}$ \\
\hline
\end{tabular}

Fonte: Moraes (2019)

Reforçando a afirmativa de Coutinho (1976), na tabela acima Motta (2012) e Sturza e Tatsch (2016) afirmam que o portunhol se consolida historicamente na oralidade do povo da fronteira e também se consolida de forma identitária. Por mais que considerem o portunhol um "erro", ou tentem não o praticar, como foi apresentado no trabalho de Lorenzetti (2016) aqui exposto, ele sempre existirá naquela comunidade de fala.

Importante destacar o conceito de identidade abordado nos estudos de Hall (2000) em que o autor argumenta que ela não é produzida de forma natural ou transcendental, mas são produzidas pelas pessoas, ou seja, é uma criação social e cultural e que acontece por meio da interação, da linguagem. Ou seja, é fundamental que se entenda que o portunhol é uma língua produzida por essas comunidades de fronteira e que é singular.

Tratar o portunhol como língua também é reforçado por Celada (2002) que sustenta que esta variante se constitui em uma "língua espontânea", já que ao ser o espanhol parecido, isto faz com que o falante de português pense que o espanhol é uma língua fácil dando uma "ilusão de competência, tornando assim sua fala espontânea, por isso o termo "língua espontânea". Este termo também poderia ser aplicado ao caso da fronteira, já que, como foi visto, a língua predominante nessa região inicialmente era o português, depois, por causa da introdução da educação formal em espanhol nas escolas, os falantes de português tiveram mais contato com o espanhol, resultando na língua espontânea do portunhol.

\subsection{Portunhol de L1 para L2/LE}


É importante ressaltar que o portunhol falado pelos habitantes bilíngues da fronteira (português uruguaio) é diferente do portunhol falado circunstancialmente por falantes monolíngues, os quais tentam se comunicar, por exemplo, em situações comerciais de fronteira ou em situações de turismo em que pessoas falantes de português tentam se comunicar em espanhol ou vice-versa. Esses falantes monolíngues também podem estar em processo (formal ou informal) de aquisição de uma segunda língua. Como explicado anteriormente, a segunda língua (L2) é aquela que é aprendida no país onde ela é falada oficialmente, dessa forma, esses casos, incluindo o portunhol circunstancial de fronteira, serão tratados como aquisição de L2. Na fronteira bilíngue a situação é diferente, já que as línguas estão em contato de forma permanente, o que não acontece no caso de aquisição de uma L2 (a não ser que o aprendiz fique de forma permanente no país onde a língua é falada oficialmente) ou aprendizado de uma LE.

Para Pacheco (2017) há diferença entre o portunhol e o português uruguaio, já que o primeiro se constitui em uma comunicação momentânea, e o segundo é uma variedade linguística praticada como língua materna pelos uruguaios da fronteira. A este respeito, Pacheco (2017) sustenta:

$\mathrm{Na}$ fronteira Brasil-Uruguai, especialmente em Aceguá, a maioria dos falantes uruguaios são bilíngues. Por isso, do ponto de vista linguístico e científico, não se pode confundir o portunhol com o português da fronteira, porque o português falado no Uruguai, especificamente em Aceguá, é língua materna e existe há mais de três séculos, pois se trata de comunidades bilíngues que falam o português e o espanhol, uma vez que o contato linguístico é estável. No caso do portunhol, seria uma tentativa de monolíngues de se comunicarem, especialmente em situações comerciais na fronteira. (PACHECO, 2017, p. 20-21)

Assim, o portunhol a que Pacheco (2017) se refere tem a ver com aprendizado ou aquisição de L2, já que em situações comerciais de fronteira, por exemplo, o falante ao tentar se comunicar em outra língua já se insere no contexto de aprendizado no país onde a língua alvo é falada oficialmente. 


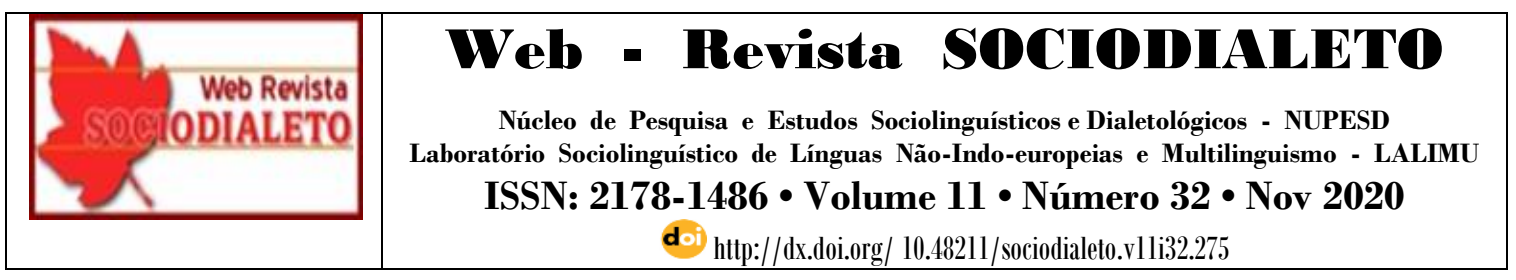

Seguindo a teoria de Selinker (1972), no aprendizado de uma segunda língua (L2 ou LE) acontece o fenômeno da interlíngua, que é um sistema intermediário entre L1 e L2/LE. Levando em conta que o portunhol falado momentaneamente ou descontinuamente na fronteira, como tentativa de comunicação, é uma forma de aprendizado de outra língua, pode-se considerar que nesse processo também há manifestação do sistema intermediário proposto por Selinker (1972). Da mesma forma, em situações formais de aprendizado de LE a interlíngua também faz parte do processo de ensino-aprendizado. Assim, pode-se dizer que o portunhol falado nesses contextos é a manifestação oral da interlíngua.

Os estudos sobre interlíngua relacionada ao portunhol na aprendizagem estão concentrados na aquisição de LE. Não foram achados estudos específicos de portunhol no contexto de aprendizado de L2 na fronteira, a não ser os estudos relacionados na seção de Portunhol de Fronteira anteriormente citados, em que alguns autores o consideram como uma interlíngua. Dessa forma, a seguir será exposto somente estudos relacionados à aquisição de LE. No entanto, será considerado que os princípios interlinguísticos que regem o aprendizado de LE são aplicáveis ao aprendizado de L2.

Segundo Carmolinga (1997) e Boésio (2001), a proximidade entre o português e o espanhol facilita a aquisição de algum deles como LE, mas somente no início do aprendizado. Em níveis mais avançados, conforme esses autores, a proximidade entre as duas línguas dificulta o melhor aprendizado. É que em um nível avançado, por exigir mais acurácia por parte do aprendiz, há mais risco de errar usando algum termo parecido nas duas línguas, mas com uso diferente. Por exemplo, o termo sino em espanhol é o equivalente ao senão em português, no entanto nem sempre possui os mesmos usos. Em alguns casos o sino usado no espanhol deverá ser substituído pela expressão mas sim em português, caso contrário, a frase resultante não terá muito sentido no português. Outro exemplo similar é o uso do apenas em português, que nem sempre será usado da mesma forma no espanhol. Esse tipo de erros acontece tanto de espanhol para português quanto de português para espanhol. Estes exemplos corroboram a manifestação do sistema intermediário (interlíngua) quando do 
aprendizado de LE, resultando, no caso de espanhol e português, em portunhol, mesmo em níveis mais avançados do conhecimento da língua alvo.

Conforme Poza e Melo (2018), a interferência do português no aprendizado de espanhol (o qual poderia ser aplicado também no aprendizado de português) na interlíngua resultante acontece mais em marcadores de caráter conversacional espontâneo do que em marcadores de caráter sintática. Ou seja, o falante erra mais em questões de caráter conversacional por se sentir mais "livre" e espontâneo, o qual não acontece com os aspectos sintáticos da fala, que possuem uma estrutura mais lógica.

Para Zolin-Vesz (2014), o portunhol resultante da interação do português e espanhol no aprendizado de uma das duas línguas não é uma interlíngua, mas constituise em uma translíngua. Nesse sentido, o autor explica que entre o português e o espanhol há uma fronteira linguística, e quando o estudante brasileiro, por exemplo, começa a aprender espanhol se "movimenta" linguisticamente em direção a essa fronteira. Assim, uma frase em portunhol seria uma "expressão translíngue", fruto do encontro entre espanhol e português na fronteira e dotada de algum sentido que o aprendiz quis lhe dar.

O conceito de translíngua será retomado mais adiante, na seção de Portunhol poético ou literário. Conforme os estudos citados, o Quadro 2 mostra a classificação do portunhol no contexto de aprendizado de L2/LE.

Quadro 2 - Classificação do portunhol de L1 para L2/LE

\begin{tabular}{|c|l|}
\hline Classificação & \multicolumn{1}{|c|}{ Características } \\
\hline \multirow{2}{*}{ Interlíngua } & $\begin{array}{l}\text { No aprendizado de L2 ou LE o falante, para se expressar, cria um } \\
\text { sistema intermediário de códigos onde há interferência da língua } \\
\text { materna (L1). No caso do aprendizado de espanhol por } \\
\text { lusofalantes (ou vice-versa), esse sistema intermediário é o } \\
\text { portunhol. }\end{array}$ \\
\hline
\end{tabular}




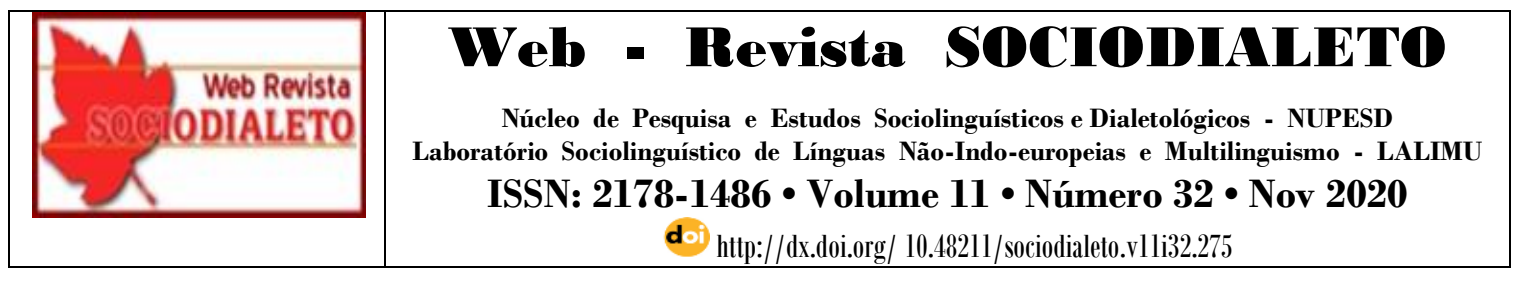

\begin{tabular}{|l|l|}
\hline \multirow{2}{*}{ Translíngua } & $\begin{array}{l}\text { Entre o português e o espanhol há uma fronteira linguística, de } \\
\text { forma que quando o estudante começa a aprender alguma dessas } \\
\text { línguas, se "movimenta" linguisticamente em direção a essa } \\
\text { fronteira. Assim, uma frase em portunhol seria uma "expressão } \\
\text { translíngue", fruto do encontro entre espanhol e português nessa } \\
\text { fronteira. }\end{array}$ \\
\hline
\end{tabular}

Fonte: Moraes (2019)

Nos casos da interlíngua e translíngua o que se pode analisar é um fator mais estático por parte da interlíngua, que parece ser regida por um conceito de códigos impossibilitando um entendimento de que a as interferências que ocorrem podem contribuir também para uma produção de "sentidos" fundamentais no ato da comunicação. Possibilidade essa que a translíngua oferece, já que, conforme Zolin-Vesz (2014), a ideia de "movimento" que existe em sua definição, ajudaria nessa construção de sentidos, principalmente no processo de ensino - aprendizagem L2/LE, mas que possivelmente se estenderia também em outros contextos, pois o que se tem percebido é que até mesmo dentro de uma mesma língua, como o português brasileiro, esse conceito de movimento em direção a uma fronteira linguística pode ser aplicado, como no caso de variedades regionais, por exemplo. Sendo assim, o portunhol se enquadraria mais numa definição de translíngua que interlíngua, defendida por muitos autores aqui apresentados. Vale ressaltar que o conceito de translíngua é recente e ainda sujeito a estudos futuros, mas que corrobora com a ideia de uma língua dinâmica sujeita a mudanças e interferências no processo de ensino/aprendizagem assim como a interlíngua.

\subsection{Portunhol poético ou literário}




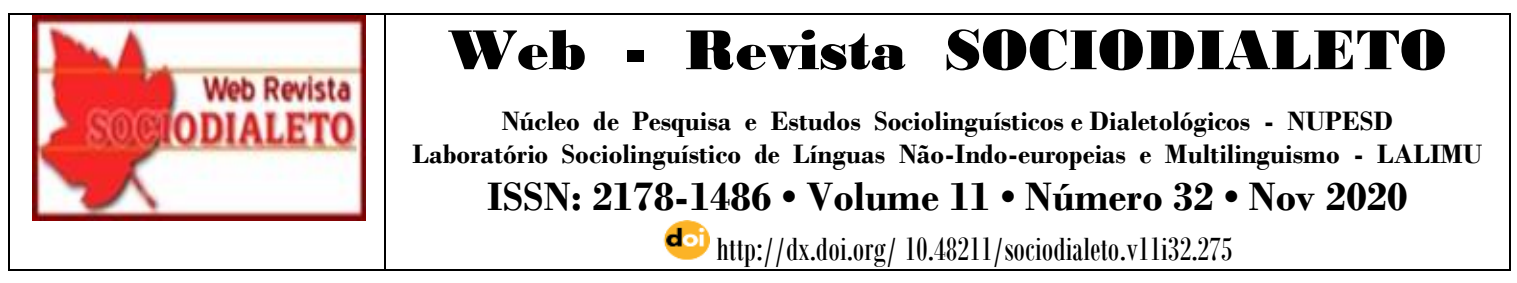

Conforme vários autores (entre eles, LIMÃO, 2015; CRINÒ, 2016; e ATTI, 2013), o portunhol na literatura surgiu com a publicação da obra Mar paraguayo do escritor brasileiro Wilson Bueno (1992), a qual seria a primeira obra literária escrita totalmente em portunhol. O poeta argentino Nélson Perlongher descreve o portunhol presente nessa obra da seguinte forma:

Há entre as duas línguas um vacilo, uma tensão, uma oscilação permanente: uma é o "erro" da outra, seu devir possível, incerto e improvável...Não há lei: há uma gramática, mas é uma gramática sem lei; há uma certa ortografia, mas é uma ortografia errática. (PERLONGHER; 1992, p. 8-9).

Esse trecho faz parte da Introdução a Mar parauayo e, dessa forma, apresenta ao leitor a "língua" com a qual essa obra seria escrita. O portunhol de Mar paraguayo consiste basicamente na mistura de português e espanhol, fazendo também alguns empréstimos do guarani. Depois de Mar paraguayo, o escritor Wilson Bueno também escreveu outras obras embora não usando inteiramente o portunhol. Como cita Souza (2015), Wilson Bueno possuía um caráter múltiplo de linguagem, resultando assim em temas e estilos variados. Ao fazer empréstimos do guarani, o portunhol de Mar paraguayo poderia ser classificado, como será visto mais adiante, em portunhol selvagem.

Outro autor literário de destaque que possui obras escritas em portunhol é o escritor uruguaio Fabián Severo. Este autor faz parte de um grupo de escritores, poetas e músicos que apresentam obras em portunhol, inseridos no contexto da fronteira Brasil Uruguai. Assim, a "língua" que esses autores usam nas suas obras é inteiramente composta pelo portunhol de fronteira discutido anteriormente na seção de Portunhol de fronteira. Isto representa uma diferença em comparação ao portunhol presente em Mar paraguaio, que, por possuir termos em guarani, se insere no contexto do portunhol da tríplice fronteira (Brasil - Argentina - Paraguai). Conforme Crinò (2016), a poesia de Fabián Severo é fronteiriça no fundo e na forma, já que as personagens, os temas e os 


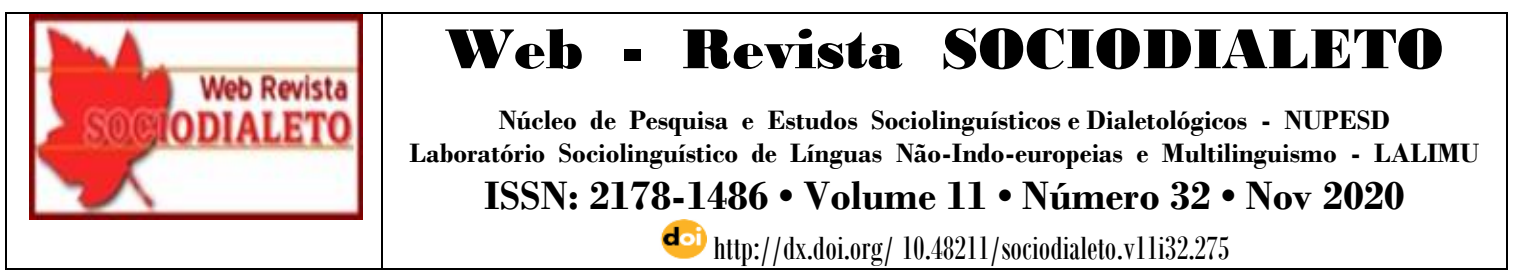

cenários apresentados nas suas obras só adquirem significado se escritos em portunhol. Para Crinò (2016), não há uma única versão escrita do portunhol, já que os autores fronteiriços o utilizam segundo o efeito poético pretendido nas suas obras, assim tais autores se constituem em "criadores de palavras", empregando a mistura de português e espanhol conforme o resultado poético desejado.

Conforme explica Abrantes (2018), o portunhol presente em obras literárias na fronteira no Norte do Uruguai se remonta à década de 40, com obras contendo, além do espanhol, portuguesismos e palavras em português e portunhol em parte dessas obras. Assim, somente em 2010, com a obra Noite nu Norte: poemas em portunhol, de Fabián Severo, o portunhol aparece inteiramente em uma obra literária na fronteira. Abrantes (2018) também explica que as obras precursoras somente apresentam uma alternância das línguas, enquanto que nas obras de Severo "a língua flui mesclada e com uma certa padronização na sintaxe e na fonologia, pois segue um estilo próprio que assumiu para escrever em uma língua tradicionalmente oral" (ABRANTES, 2018, p. 85). Além de Noite nu Norte: poemas em portunhol, Severo também possui outras obras lançadas inteiramente em portunhol.

Por se tratar de portunhol escrito no contexto da fronteira Brasil - Uruguai, em que as línguas de base são o português e o espanhol, este tipo de escrita literária será classificado simplesmente como portunhol literário, que difere do portunhol selvagem, que além de português e espanhol inclui outras línguas. O portunhol selvagem será exposto a seguir.

\subsection{Portunhol selvagem}

O nome portunhol selvagem foi criado pelo autor Douglas Diegues, que começou a usá-lo a partir da publicação da obra Dá gusto andar desnudo por estas selvas: sonetos salvajes, em 2002. Conforme o próprio autor, ele sustenta que: “[...] además del guarani, posso enfiar numa frasse palavras de mais de 20 lenguas ameríndias 


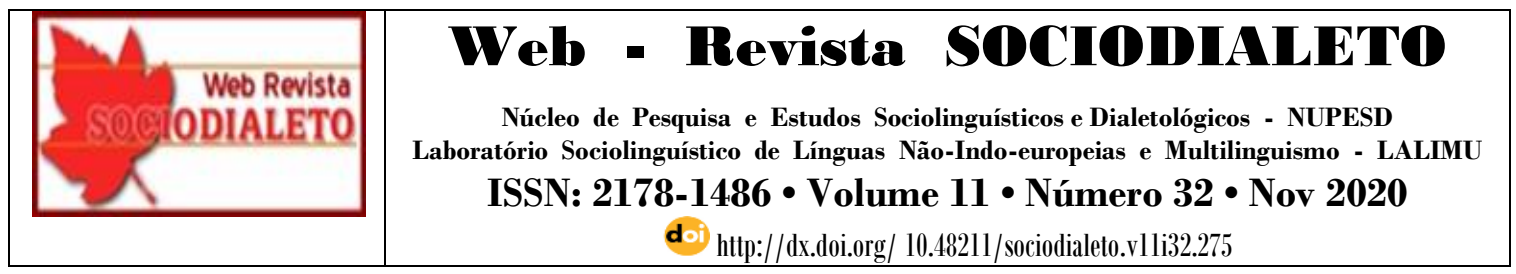

que existem em Paraguaylândia y el resto de las lenguas que existem em este mundo. [...]”. (DIEGUES, 2009).

Assim, o portunhol selvagem usa portunhol convencional, guarani e outras línguas, conforme o resultado que o autor deseja alcançar em seus textos. A obra Mar paraguayo do autor Wilson Bueno, escrita dez anos antes, seria a precursora do portunhol selvagem e, conforme Rocha (2011), Diegues seria seu sucessor. A partir da sua primeira publicação em portunhol selvagem, em 2002, todas as obras posteriores do autor Douglas Diegues são escritas nessa "língua". O termo portunhol selvagem começou a ser referenciado como tal pelo próprio autor somente a partir da sua segunda obra: Uma flor na solapa da miséria.

Para Locane (2015), que chama o portunhol selvagem de guaraportunhol, a literatura escrita nessa variante exalta deliberadamente o portunhol falado na tríplice fronteira (Brasil, Argentina e Paraguay), tornando-o assim em artificial. Para o autor, o portunhol selvagem se constitui em uma apropriação e exaltação poética de uma língua efetivamente em uso. Assim, o portunhol selvagem reflete a variante falada na tríplice fronteira, no entanto os autores literários que o usam readéquam esta variante, ressaltando ou exaltando poeticamente suas principais características.

Segundo Amarante (2009), o portunhol selvagem é uma língua artificial criada a partir do vocabulário de outras línguas já existentes, entre elas o espanhol, português e guarani, assim, o portunhol selvagem seria uma língua artificial criada a posteriori. Como língua criada artificialmente, outra característica do portunhol selvagem é que não possui regras e, dessa forma, pode ser usada seguindo a vontade de quem faz uso dessa língua.

A autora Alves (2017) coloca o portunhol selvagem em posição de resistência à ideologia dominante que determina as normas cultas de fala e escrita da língua. Para o autor, o termo "selvagem" indica uma forma de ser livre, original, "não domesticado", em meio à normatização imposta pela ideologia dominante. Assim, o portunhol selvagem seria um dos resultados de um processo de contraidentificação ideológica originado na fronteira, onde a norma imposta está muito distante da realidade dos 


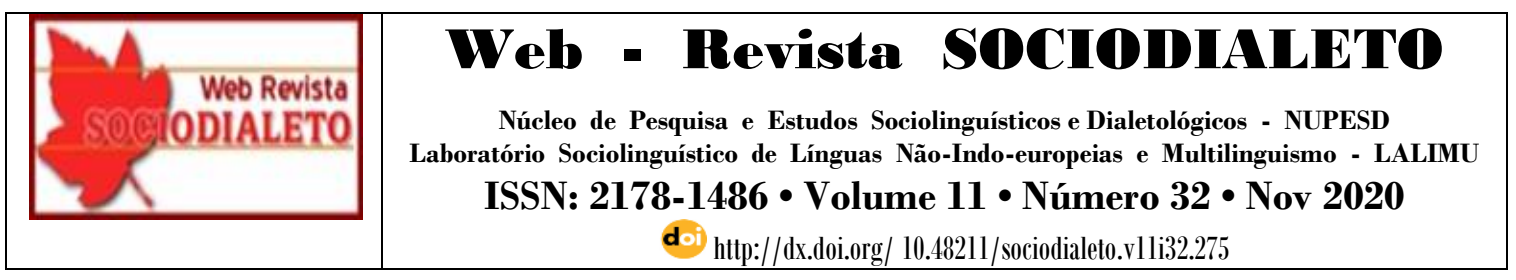

sujeitos que a habitam. Esses sujeitos, ao questionar as normas impostas, dão lugar ao processo de contraidentificação, que tem como um dos seus resultados a escrita em portunhol selvagem, o qual, por sua vez, reforça e legitima a resistência.

Para Peres (2018), o portunhol selvagem é uma língua poética inventada pelo autor Douglas Diegues, que usa como base a hibridação linguística e cultural que acontece na tríplice fronteira. Ao escrever em portunhol selvagem, Douglas Diegues distancia-se do conceito de nação e resgata a identidade híbrida da fronteira. Ou seja, o portunhol não define o pertencimento a algum país, mas retrata uma realidade em que dois ou mais países se encontram e os textos em portunhol legitimam e mantém essa identidade fronteiriça.

O Quadro 3 mostra as principais colocações de Locane (2015), Amarante (2009), Alves (2017) e Peres (2018). Pode-se observar no Quadro 3 que a maior parte dos autores citados enquadra o portunhol selvagem como língua, especificamente Locane (2015), Amarante (2009), e Peres (2018). O portunhol literário, descrito anteriormente, também é enquadrado como língua por Abrantes (2018).

Conforme os estudos dos autores pesquisados, tanto o portunhol literário quanto o portunhol selvagem representam e reafirmam a identidade das comunidades de fala por meio da escrita. Ambos os estilos, embora retratem a realidade linguística da fronteira, são fruto da criação do escritor ou poeta que deseja fazer uso do portunhol. Como cita Celada (2002), é onde o poeta tem a possibilidade de se "entregar a uma Babel do inconsciente". A autora argumenta que o poeta explora um entremeio e encontra a forma de desterritorialização tanto da língua portuguesa quanto da língua espanhola nesse entremeio que seria o portunhol.

Quadro 3 - Características do portunhol selvagem

\begin{tabular}{|c|l|l|}
\hline Autor & Denominação & \multicolumn{1}{|c|}{ Características } \\
\hline \multirow{2}{*}{$\begin{array}{l}\text { Locane (2015) } \\
\text { Portunhol } \\
\text { selvagem }\end{array}$} & $\begin{array}{l}\text { O portunhol ou guaraportunhol é uma língua } \\
\text { literária que possui como característica } \\
\text { principal uma variante do portunhol com } \\
\text { nuances de guarani. }\end{array}$ \\
\hline
\end{tabular}




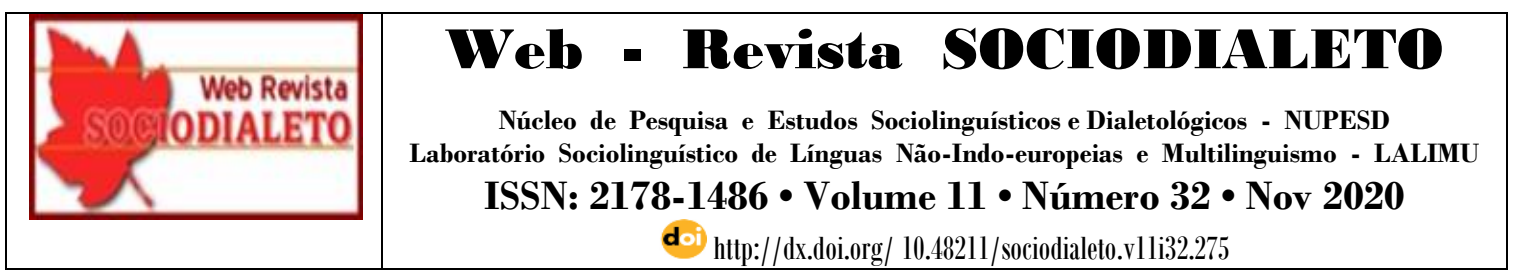

\begin{tabular}{|l|l|l|}
\hline & guaraportunhol. & $\begin{array}{l}\text { Os textos redigidos em portunhol possuem uma } \\
\text { deliberada exaltação estética, manifestada } \\
\text { poeticamente, que faz com que a língua se } \\
\text { torne artificial. }\end{array}$ \\
\hline $\begin{array}{l}\text { Amarante } \\
\text { (2009) }\end{array}$ & $\begin{array}{l}\text { Portunhol } \\
\text { selvagem. } \\
\text { partir de outras línguas já existentes, entre elas } \\
\text { o português, espanhol e guarani, assim, é uma } \\
\text { língua artificial a posteriori. } \\
\text { O portunhol selvagem não possui regras, pelo } \\
\text { qual pode ser usado segundo a vontade do } \\
\text { falante/escritor. }\end{array}$ \\
\hline Alves (2017) & $\begin{array}{l}\text { Portunhol } \\
\text { selvagem. }\end{array}$ & $\begin{array}{l}\text { O portunhol selvagem é um dos resultados de } \\
\text { um processo de contra identificação ideológica } \\
\text { na fronteira, assim este se constitui em uma } \\
\text { forma de resistência aos padrões da norma } \\
\text { culta. O portunhol selvagem na forma escrita } \\
\text { legitima tal resistência. }\end{array}$ \\
\hline Peres (2018) & $\begin{array}{l}\text { O portunhol selvagem é fruto de uma } \\
\text { hibridação linguístico-cultural que ocorre na } \\
\text { Tríplice Fronteira. }\end{array}$ \\
poétivagem; Língua & $\begin{array}{l}\text { O portunhol selvagem resgata e reafirma a } \\
\text { identidade fronteiriça, se afastando do conceito } \\
\text { de nação ou pertencimento algum país. }\end{array}$ \\
\hline
\end{tabular}

Fonte: Moraes (2019)

\section{Considerações finais}

Este trabalho buscou classificar o portunhol como língua, interlíngua, dialeto ou outra variante, segundo o contexto em que é praticado, a partir de uma análise de estudos relacionados ao tema. Conforme os estudos levantados, foi constatado que a classificação do portunhol depende de três contextos nos quais está inserido: portunhol de fronteira, portunhol no contexto de ensino/aprendizagem e portunhol literário.

No caso de portunhol de fronteira, foi constatado que a maior parte dos estudos o classifica como dialeto ou variedade do português. No entanto, por ser uma variante histórica e socialmente consolidada, representando a linguagem particular do povo da fronteira, além de representar sua identidade, pode ser considerado uma língua. 


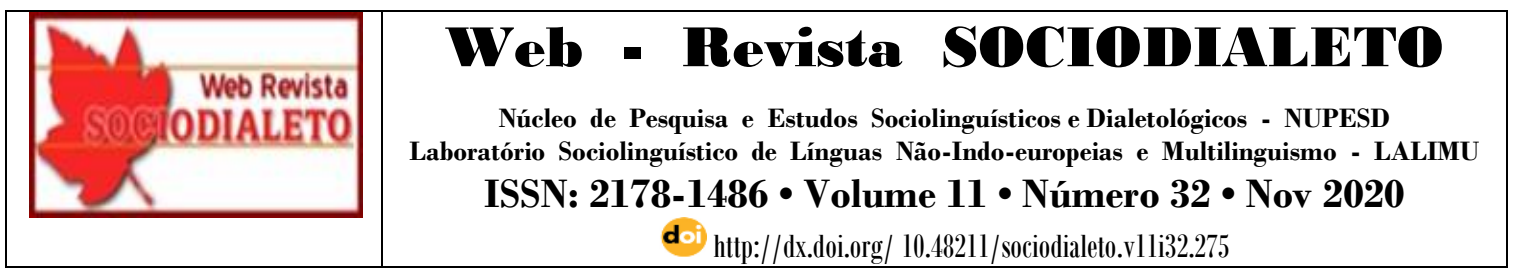

O portunhol no contexto de ensino/aprendizagem (portunhol de L1 para L2/LE) pode ser considerado uma translíngua, contrastando com o conceito de interlíngua, já que a primeira fornece um sentido de maior dinamicidade e movimentação entre o espanhol-português ou vice-versa, eliminando o sentido mais estático do conceito de interlíngua.

Quanto ao portunhol literário, tanto o portunhol poético como o literário, pode ser classificado como língua literária, já que possui uma linguagem particular e única, representando a realidade linguística da fronteira.

Assim, atende-se o objetivo principal deste trabalho, e recomenda-se para trabalhos futuros aprofundar o estudo do portunhol no contexto de ensino/aprendizado, especificamente no sentido de translíngua, já que se percebe a falta de estudos nesse campo. Pela mesma razão recomendasse aprofundar os estudos sobre portunhol literário e portunhol falado em outras fronteiras brasileiras que não as citadas neste trabalho.

\section{Referências}

APPEL, R.; MUYSKEN, P. Bilinguismo y Lenguas en Contacto. Barcelona: Ariel Linguística, 1996.

ATTI, F. Considerações acerca do movimento do Portunhol selvagem: o paradigma da osmose e a resistência cultural. Babilónia, Línguas Culturas e Tradução, n. 13, p. 47-72, 2013.

BEHARES, L. E. Educação fronteiriça Brasil/Uruguai, línguas e sujeitos. Proposições, v. 21, n.3 (63), p. 17-24. 2010.

BOÉSIO, C. P. D. Espanhol e português: proximidade, transferências, erros e correções na flexão do infinitivo. Comunicação ao II FILE - Fórum Internacional de Língua Estrangeira. Pelotas, UCPEL e UFPEL, 2001.

BUENO, W. Mar Paraguayo. São Paulo/Curitiba: Iluminuras/Secretaria de Estado da Cultura do Paraná, 1992. 80p.

CARVALHO, A. M. The social distribution of Uruguayan Portuguese in a bilingual bordertown. Berkeley, 1998. Tese (Doutorado) - University of California.

CARVAlHO, A. M. Rumo a uma definição do português uruguaio. Revista Internacional de Linguística Iberoamericana, v. 1, n. 2, p. 125-149, 2003. 


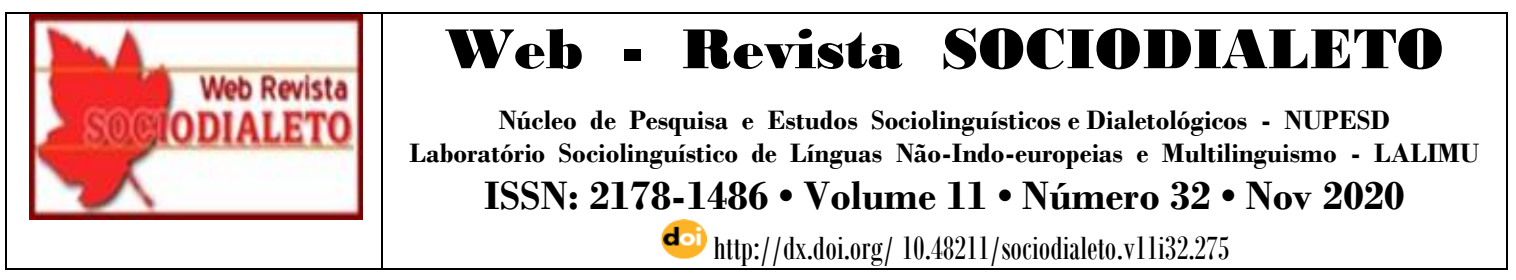

CELADA, M. T. O espanhol para o brasileiro: uma língua singularmente estrangeira. Campinas, 2002. 277 f. Tese (Doutorado em Linguística), Universidade de São Paulo.

CHASTEEN, J. C. Fronteira Rebelde: a vida e a época dos últimos caudilhos gaúchos. Porto Alegre: Movimento, 2003. 227p.

COUTINHO, Ismael de Lima. Pontos de Gramática Histórica. Rio de Janeiro: Ao livro técnico. 1976.

CRINO, C. Portunhol/Portuñol na poesia de Fabián Severo. Revista Interfaces, v. 24, n. 1, p. 35-53, 2016.

ELLIS, R. Second Language Acquisition. Oxford: Oxford University Press, 1997.

ELIZAINCÍN, Adolfo. 1992. Dialectos en contacto: español y portugués en España y América. Montevideo: Arca.

ELIZAINCÍN, A.; BEHARES, L.; BARRIOS, G. Nos falemo brasilero. Montevideo: Editorial Amesur, 1987.

FAULSTICH, Enilde. O portunhol é uma interlíngua? Seminário apresentado no Institut Universitari de Lingüística Aplicada (IULA), Universitat Pompeu Fabra (UPF), Barcelona, em 21 de abril de 1997.

FERGUSON, C. A. Diglossia. In: GIGLIOLI, P. P. (Org.). Language and social context: Selected readings. Baltimore: Penguin, 1972. p. 232-251.

GLOBO. Diário de Notícias. Centenas de milhares de uruguaios têm o português como língua materna. 2015. Disponível em: $<$ https://www.dn.pt/globo/interior/centenas-de-milhares-de-uruguaios-tem-portuguescomo-lingua-materna-4751661.html> Acesso em: 08/04/2019.

HALL, S. Quem precisa da identidade? Tradução de Tomaz Tadeu da Silva. In: SILVA, T. da; HALL, S.; WOODWARD, K.. Identidade e diferença. A perspectiva dos estudos culturais. Petrópolis: Editora Vozes, p. 73-101, 2000.

HENSEY, F. G. Uruguayan fronterizo: A linguistic sampler. Word, v. 33, n. 1-2, p.193-198, 1982.

HENSEY, F. G. El fronterizo del Norte del Uruguay: interlingua e interlecto. Foro Literário, Montevideo, n. 7-8, p. 54-59, 1980.

LIPSKI, John M. Selected Proceedings of the 8th Hispanic Linguistics Symposium, ed. Timothy L. Face and Carol A. Klee, 1-22. Somerville, MA: Cascadilla Proceedings Project. 2006.

LIPSKI, J. Too close for comfort? The genesis of portuñol/portunhol. In: HISPANIC LINGUISTICS SYMPOSIUM, 8, 2006, Somerville. Anais...Somerville: Cascadilla Proceeding Project, 2006.

LIMÃO, P. O “portunhol” da américa latina no ciberespaço: de interlíngua e língua de fronteira a língua de intercompreensão e língua literária sem fronteiras. 


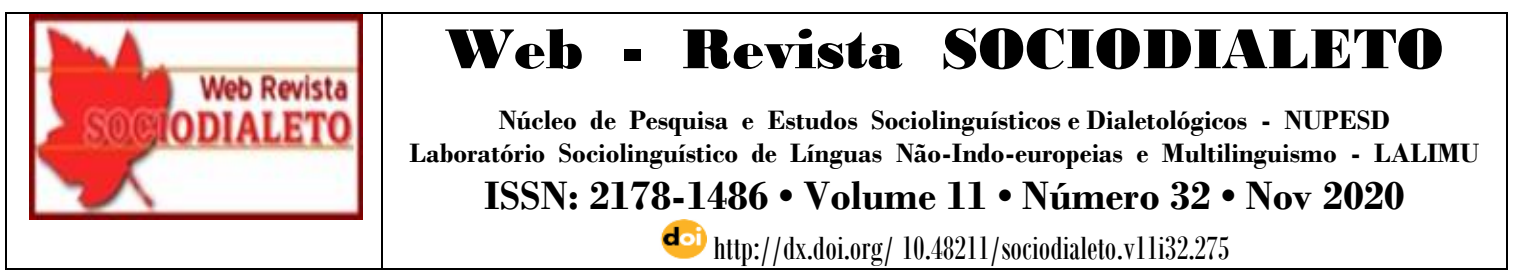

In: SIMPÓSIO MUNDIAL DE ESTUDOS DE LÍNGUA PORTUGUESA, 5, 2015, Lecce. Anais...Lecce: ESE, 2015, p. 141-157.

LOCANE, J. Disquisiciones en torno al portunhol selvagem: del horror de los profesores a una "Iengua pura". Perífrasis, v. 6, n. 12, p. 36-48, 2015.

LORENZETTI, Al. N. O Programa Escolas Interculturais de Fronteira (PEIF) como política linguística educacional: estudo na fronteira das cidades de São Borja (Br) e Santo Tomé (Ar). 2016. 282f. Dissertação (Mestrado em Linguagem, Identidade e Subjetividade), Universidade Estadual de Ponta Grossa.

MORALES, G. O portunhol: língua, interlíngua ou dialeto. (IN)Genios, v. 2, n. 2, p. $1-10,2016$.

MOTA, S. S. Línguas, sujeitos e sentidos: o jornal nas relações fronteiriças no final do século XIX, início do século XX. 2010. Dissertação (mestrado em Letras). Universidade Federal de Santa Maria. Santa Maria.

MOTA, S. S. Portuñol, sujeito e sentido: efeitos de uma política educacional em Noite nu Norte. Abehache, ano 2, n 3. jul./dez. 2012.

PERLONGHER, N. Introdução. In: BUENO, W. Mar Paraguayo. São Paulo/Curitiba: Iluminuras/Secretaria de Estado da Cultura do Paraná, 1992. 80p.

PACHECO, C. Como definir o falar da fronteira Brasil-Uruguai? Revista (Con) Textos Linguísticos, v. 11, n. 19, p. 9-28, 2017.

PERES, W. O Portunhol Selvagem: uma revolução na linguagem com imagens resgatadas do inconsciente coletivo. Revista Tabuleiro de Letras, v. 12, n. 1, p. 177189, jun. 2018.

POZA, J.; MELO, G. A interferência linguística no processo de ensinoaprendizagem da língua espanhola em professores e aprendizes brasileiros. Afluente, v.3, n. 9, p. 45-61, set./dez. 2018.

RONA, J. P. La frontera linguística entre el portugués y el español en el norte del Uruguay. Veritas, v. 8, n. 2, p. 201-221, 1963.

RONA, J. P. El dialecto "fronterizo" del norte del Uruguay. Montevideo: Adolfo Linardi, 1965. 45 p.

SELINKER, L. Interlanguage. International Review of Applied Linguistics, v.10, p.209-231, 1972.

SOUZA, S.B.; PRADO, F.P. Brasileiros na fronteira uruguaia: economia e política no século XIX. In: GRIJÓ, L.A.; KUHN, F.; GUAZELLI, C.A.B.; NEUMANN. E.S. Capítulos da História do Rio Grande do Sul. Porto Alegre. Editora da UFRGS. 2004.

STURZA, E.; TATSCH, J. A fronteira e as línguas em contato: uma perspectiva de abordagem. Cadernos de Letras da UFF Dossiê: Linguas e culturas em contato, n. 53, p. 83-98, 2016. 


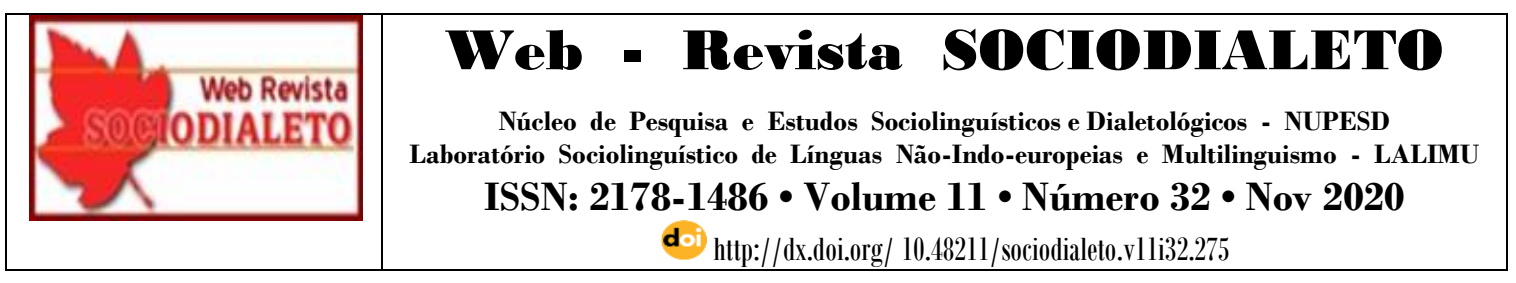

THUN, H.; FORTE C.; ELIZIACÍN, A. El Atlas Lingüístico Diatópico y Diastrático del Uruguai (ADDU): Presentación de un proyecto. Iberorromania, n.30, p. 26-62, 1989.

ZOLIN- VESZ, F. Como ser feliz em meio ao portunhol que se produz na sala de aula de español: por uma pedagogia translingue. Trabalhos em Linguíistica Aplicada, v.3, n.52, p.321-332, jul./dez.2014.

Recebido Para Publicação em 30 de março de 2020.

Aprovado Para Publicação em 30 de outubro de 2020. 